\title{
E-democracy and citizen's empowerment: a case study of the city of Madrid
}

\author{
J. M. V. Santos \& Á. I. Alonso \\ Department of Public Law and Political Science, \\ University Rey Juan Carlos, Madrid
}

\begin{abstract}
One of the main concerns regarding democratic theory is dealing with the fostering of active citizen engagement in the making of public policies. With this in mind, in the year 2003 the local government of the city of Madrid (Spain) designed a broad Citizen's Participation Policy. One of the main elements within this policy was the use of NICT and Internet in order to reinforce citizens' participation and voice. This contribution examines structural democratic issues and how the NICT is used to enhance governance in this large European city. The paper concludes with a discussion of the implications for future research and advice for politicians and public officials using e-participation as a strategy for enhancing local democracy and network governance as well as supporting greater citizen involvement in public decision making.

This contribution is part of a Research Project on E-DEMOCRACY headed by David Ríos Insua and financed by the Madrid Regional Government under the IV Regional Plan for Scientific Research and Technologic Innovation (PRICIT).
\end{abstract}

Keywords: democracy, e-democracy, e-governance, local government, new information technology.

\section{Introduction}

E-democracy involves the use of information technologies to improve the relationships between the public and the government entities in terms of citizens' participation and public service delivery [1]. It could be argued that the Internet and e-democracy are being used to improve both the engagement of citizens in 
public affairs and the quality of public services, particularly in city governments [2].

Under the present circumstances the convergence of more general processes generates a pressure on those governments which, for political legitimacy, have to implement untried policy options and experiments in democratic innovation. While those city governments may be constrained by the forces of globalism they are also active in developing strategies to improve democracy and, therefore, the local level has become an excellent laboratory for democratic innovations. In fact, the increasing importance of local government is the consequence of two intensive trends (not necessarily compatible) which exist today and are, in many ways, a reflection of the times in which we live. Those two trends are, firstly, the desire to improve and extend representative democracy which, many believe, is too superficial and restricted and, secondly, the unstoppable progress of the process of globalization, which has changed the traditional rules of politics and, consequently, those of administration.

Liberal representation is undoubtedly an ingenious intellectual invention, but lacks sufficient credibility. Certainly, democracy based solely on the traditional party system has served to deepen this crisis, and in addition, liberal representation has been superseded by historical advance. Political parties are no longer an aid but rather an obstacle to the satisfaction of new demands and forms of participation. Thus, it is not surprising that citizens, especially in a postmaterialistic political culture, demand from their most immediate political administrations the improvement and extension of political participation. There is no doubt that the new demands for participation at local level are also demands for increased control over the public authorities and the decisions they take. Thus, an increase in civic participation is also an increase in control mechanisms and in the accountability of local authorities.

Overall, however, these changes have not yet produced a general and coherent transformation of the political sphere [3]. Consequently, it would be premature to affirm that representative democracy has been replaced by participatory democracy. Today, the most we can say is that there is a significant tendency to introduce participatory democracy at the local level, where there is less risk and difficulty in so doing. In general terms, we may assume that in the future a new political structure could emerge, to compete with or even replace, to a certain extent, representative democracy.

However, there are many problems to overcome. For instance, it may be that the majority of the new experiments in democratic innovation end in failure because they produce a reduction in the political sphere. Another possibility is that such experiences are unequally distributed and improve the quality of democracy in some places but not in others. Therefore, the general concept of democracy that has been linked to the existence of the nation-state must be reviewed. As a result, it may be necessary to reflect upon the consequences that an apparently emancipating policy would have on the defence of democratization at the local level and on the reinforcement of a communitarian idea of politics and its criticism of the concept of citizenship. 
As suggested above, the increase in the number and depth of studies of local participation is due not only to the interest displayed regarding those practices which may improve and extend traditional representative democracy, but also to the crisis of the nation-state and its political structures.

\section{Democracy and local government}

The defence of local democracy and its improvement through electronic means should not lead us to forget the problem of the health and quality of democracy at a more general level [4]. Rather one of the most difficult problems to be resolved is not that of the attempt to improve democracy but of how to situate new forms of participation within a wider project of democratic expansion. It should be noted that local autonomy refers only to those aspects which are strictly local, since many core elements at the local level depend, in reality, on other levels of government. In other words, the local level can only be understood within a more general context. However, there is a body of conservative thought which is interested in the local level not so much because of its undoubted belief in the value of local democracy per se, but rather because it is convinced that the local tier can be employed to confront other levels of government. Whatever the case, local democracy cannot be used to attack the central general government (duly endorsed by the popular will) as some founding fathers of the American Constitution argued, as well as de Tocqueville and a number of similarly minded conservative and liberal thinkers of the $18^{\text {th }}$ century.

As suggested above, another trend which should not be ignored, as it provides a framework for recent developments in autonomy at local level, is that of globalism and globalization. Globalization processes are undoubtedly posing a threat to local governments, particularly those of large cities, since it is the local level which is becoming more and more closely connected to the global order. The internationalization of capital forces local communities to strive for greater autonomy and decision-making capacity in order to try to solve their problems, especially those related to economic welfare. As a result, such local communities require greater development of their civil society and democratic practices. This pressure on specific localities is justified by the comparative economic advantages enjoyed by such communities in comparison to their states. Furthermore, we must add the costs in terms of territorial inequality associated with the decreasing dependence on the national level of government. It is then that the dangers then become obvious. It is easy to imagine the following situation - the existence of various well-connected local communities, economically and politically strong, and in which there is a very advanced civic culture with regard to new forms of democratic participation, but which are, however, surrounded by other communities which have not enjoyed a similar degree of progress.

We may conclude, as a result, that reflections upon innovation in local democracy should recognize the duality of underlying forces and the possibilities and risks these processes produce. The most important lesson to be extracted 
from the above is to ensure that these new democratic practices improve democracy not only at the local but also at the national level.

\section{The contours of e-democracy and e-participation at the local level: local governance, social capital, and the modernization of public administration}

The relationships between local democratization and social capital, first formulated by Putnam [5], are a new version of the classic problem of the relationships that exists in civil society and the possibilities for the development of democracy. In other words, this is the type of political culture operating in civil society and democracy today.

Similarly, Pratchett [6] analyzes if democracy and social capital are independent of each other; then, in fact, social capital is not the independent variable. Pratchett similarly considers the negative consequences for local democracy regarding the existence of social capital in a state with an unequal territorial distribution.

This said, Lowndes and Wilson [7] believe institutional arrangements have an important influence upon social capital, and that social capital can be developed as an institutional policy. The conclusion is quite clear: a "spontaneous, natural and autonomous" development of social capital cannot be expected. Instead the improvement of citizens' participation will arise from institutions intervening to create homogeneous and strengthened social capital in place of a factor which was hitherto weak and unequally distributed.

Equally, there are specific problems regarding participation practices at the local level. A considerable number of authors are in agreement regarding some key questions which arise from every democratic innovation experiment and process. For example, there is a continuous production of studies regarding fairness, empowerment, disempowerment, governance, efficiency, efficacy, evaluation of procedures and results, the coordination of participation, etc. The nature of these studies is varied because they usually include both empirical and normative approaches, which allow a comparative analysis to be made. Subsequently, strengths and weaknesses of each example of democratic innovation can be inferred.

Other authors classify the range of democratic innovations according to such concepts as representation and legitimacy [8]. The importance of normative judgments seems obvious in this classification, when they are made on the basis of the capacity of each participation exercise that incorporate citizens into the democratic process. In other words, in these studies the most important factor is the degree of legitimacy. In such research there are two areas of special interest. They include:

1. Studies of the breadth of participation (how many participate, if the participants are representative, what kind of representation is sought what criteria of selection are employed, who has chosen those criteria, etc.), the kind of participation desired and obtained (information, co-management, 
consultation or co-decision) and the nature and quantity of the resources of the participants.

2. Studies of those issues where participation is easier and the results of such participation (i.e. whether participation has influenced the final decisions).

By contrast, however, there exist a number of (similarly normative) pieces of research in which classifications are made according to the effectiveness and efficiency of the different processes. In these studies the principal aim is to obtain results and costs (measurable in terms of money, time and human resources) involved in reaching those final outcomes. In addition, effectiveness and efficiency can be defined from a mercantile or a public point of view [9].

\section{Local governance and e-participation}

Governance of the local political and administrative system is closely linked to civic participation where the hierarchy, as an instrument of coordination, is substituted by a variety of networks comprised of individual and collective actors with different degrees of institutionalization (i.e. governance as an alternative to hierarchies).

The characteristics defining this form of coordination are the search for a continuous consensus and group decision-making. The latter characteristic is an instrumental rationality based on hierarchies (top-down instructions) substituted by Habermasian communicative rationality, which is grounded in negotiation with and among responsible citizens [10]. Civic participation processes at the local level are thus located within the framework of the governance of complex societies. Such governance requires a redefinition of the dynamics between citizens and the political and administrative system. This, in turn, will improve the processes by which society formulates its objectives, as well as expand the means to achieve them.

Differentiation processes challenge the capacity of local political and administrative systems to make decisions in the name of the public interest. Without considering the question of whether public interest is something that local governments may find difficult to resolve in isolation, structures of hierarchical coordination and administrative rationality will rely exclusively on "expert" knowledge that are no longer functional. As a result, it is imperative to adopt criteria of social relevance that must include the process through which public decisions are made via the establishment of a communicative process on which the orientation of administrative actions depends. Thus, local governance requires the construction of space available to the public in which reflection and debate is made possible.

In the local political and administrative subsystem citizen participation policies are aimed at enabling governance. Moreover, it is at the local level where the limits between the political and administrative system and civil society are more permeable. As a result, citizen participation policies are much more visible, have greater impact upon the citizenry and are consequently placed high on the political agenda. 
It is at local government level where the state is most clearly seen as a "negotiating state" [11]. Local government becomes one actor among many and it is by no means a dominant actor - for the resolution of urban problems it depends on other interests. It is through civic participation processes that interaction between citizens and the political and administrative system occurs. Both local civil society and local governments are involved in broader social, political, economic and cultural processes. On this point, local governance theory offers a distinctive approach and provides a framework for analysis that encapsulates important aspects related to the issue of civic participation, since it emphasizes the interaction between the political, administrative and societal systems in achieving common goals.

\section{The initiative of Madrid for enhancing civic e-participation}

To foster citizens' participation and empowerment, through e-democracy, the local government of Madrid has promoted electronic initiatives. We shall concentrate on one experiment carried out in one district council. Our analysis is intended to facilitate consideration of the implementation of these initiatives and their outcomes. For the purposes of our research, e-participation policies is understood to mean those administrative and political actions which facilitate local governance by fostering interaction between the local political and civil society.

The City of Madrid has a political culture and a social structure that foster civic participation. This city is the national capital of the Kingdom of Spain, has a population of 3.5 million, and is today a major economic and cultural player in the European Union. With well-organized political parties and high rates of electoral participation, the vote is split amongst three parties (PP, PSOE and IU), which dominate the branches of Spain's major national parties,

During the 1960s and 1970s huge internal migrations sharply increased the City's population, creating "banlieu" neighbourhoods. These areas were ripe for social conflict. In many respects, their political exclusion derived from the existence of an autocratic political regime. In the absence of political parties, a significant number of associations (economic, social, cultural, etc.) developed in a vindicative style.

Spain's first democratic local government elected in 1979 approved, in 1982, the first local regulations on citizens' participation. They focused primarily on the creation of the Councils at district level. Due to the limited resources available these councils were unable to channel citizens' demands. Furthermore, many of the civic leaders were co-opted by the political parties. Since then participation remained weak and in 1987 an effort to revitalize citizen participation was made through a cooperative agreement between the city government and the Regional Federation of Associations.

Together, though at the regional level, an important turning point took place in 1997 with the so-called "Investment Plan Villaverde-Usera". This Plan, an important instrument of cooperation between the regional government and the associations, was greeted by the associative tissue of the city since it represented 
the dismantling of the so called "markets of drugs". More importantly, it was meant to have substantive and positive impacts. The Plan showed a real commitment that sought to eliminate the historic social divide between the southeast area of Madrid and the rest of the capital.

The recent 2003 local elections brought a new Mayor from the right-wing party Partido Popular (PP) into power. He also happened to be the former President of Madrid's regional government. His agenda is now taking shape and has put forward a system that affords opportunities for neighbourhood expression. In 2004 a new model of citizens' participation in the City of Madrid has been implemented. The normative framework that was approved links citizens' participation with the modernization of the city government. In this model, the city-wide institutions are supplemented by Territorial and Sectorial Councils that influence a wide range of policy areas. The institutions also permit public participation in some decisions. In addition, the funding for associations has been increased. Prior to this change a low level of civic involvement correlated with a low level of neighbourhood empowerment.

As an initial step towards e-democracy an electronic survey was carried out in the Hortaleza District of Madrid [12]. Citizens were asked for their inputs on how to prevent vandalism in one of their main public parks. Under the leadership of the district councillor and the proactive role of the district administrators, the survey was prepared by the District Council, the neighbourhood associations and other stakeholders located in the District. Furthermore, the administration provided the necessary technical support. Over 192 citizens, out of a voting population of 21.352, answered the survey using Internet facilities. Beyond participation, even beyond empowerment, the exercise was set up to encourage citizens to work together with the local government. According to the main stakeholders, this exercise can be viewed as a contribution to the civil culture of the district, namely through the building of social capital. In Madrid, there are signs of change regarding civic involvement in public affairs. Efforts are being made to materialize it. There are, of course difficulties. Bear in mind that the exogenous social fragmentation of the city exists. Also, the endogenous fragmentation and tensions within the administrative machinery and between the different conceptions of citizens' participation policy and instruments persist.

\section{Conclusion and implications}

Several important lessons can be drawn from this case. Madrid's initial experience demonstrates how an early stage of e-democracy development that uses technologies to engage citizens in deliberative forms of democracy may require extra time and effort on the part of local politicians and public officials.

Although the adoption of e-democracy will increase citizens' engagement in local government, public officials still continue to be quite hierarchical in their approach to citizens' participation. Therefore e-democracy development requires some sort of political leadership that will enhance democracy.

Again, due to the low level of participation, it is debatable how to legitimize the representation and promotion of the rights of the whole community. Another 
complication has to do with the problem of equitable access and digital divide which includes the low levels of computer literacy. In this respect one of the priority actions of the local government should be to initiate computer literacy programs that will help reduce the internet gap within neighborhoods.

All the same, it cannot be denied that the use of electronic tools can provide important benefits for citizens, politicans and public officials. We are at an early stage in the use of new technologies to foster democracy and e-governance and much still remains to be explored. For example, additional comparative research is needed, focusing on evaluative studies addressing the inhibitions or constraints that make it difficult for the citizens to play a part in public decision-making.

\section{References}

[1] Kailor, C.H., Deshazo, R., Van Eck, D. (2001), Gauging e-government: a report on implementing services among American cities. Government Information Quarterly, 18, 293-307.

[2] Alexander, C.J. and Pal, L.A. (1998). Digital democracy: Policy and politics in the wired world, Oxford: Oxford University Press.

[3] Barber, B. (1984). Strong democracy: Participatory politics for a new age. Berkeley: University of California Press.

[4] Dutton, W.H. (1999). Society on the line: Information politics in the digital age. Oxford: Oxford University Press.

[5] Putnam, R. (1993). Making Democracy Work. Civic Traditions in Modern Italy, Princenton University Press.

[6] Pratchett, L. (1999). "Citizens, Localities and the State: Modernising Democracy?" Paper presented at the ECPR Joint Sessions of Workshops, Copenhagen, 14-19 April.

[7] Lowndes, V. y Wilson, D. (2000). "Social Capital and Local overnance: Exploring the Institutional Design Variable", Paper Presented for the 28th ECPR-Joint Sessions of Workshops, Copenhagen, 14-19 April.

[8] Webler, T. Y S. Tuler (2000). "Fairness and Competence in Citizen Participation. Theoretical Reflections from a Case Study", Administration \& Society, 32, 5, p. 566-595.

[9] Vries, M. de (2000). "La bureaucratisation de la participation", Revue International des Sciences Administratives, 66, 2, p. 385-412.

[10] Sanderson, I. (1999). "Participation and Democratic Renewal: From Instrumental to Communicative Rationality", Policy \& Politics, 27, 3, p. 325-342.

[11] March, J. and Olsen, J. (1995), Democratic Governance, Free Press, New York.

[12] Ayuntamiento de Madrid (2005). Improving citizen participation through the use of electronic voting. A sociological report regarding Citizen Consultation on the "Huerta de la Salud" Park in the Hortaleza District. Ayuntamiento de Madrid. 